
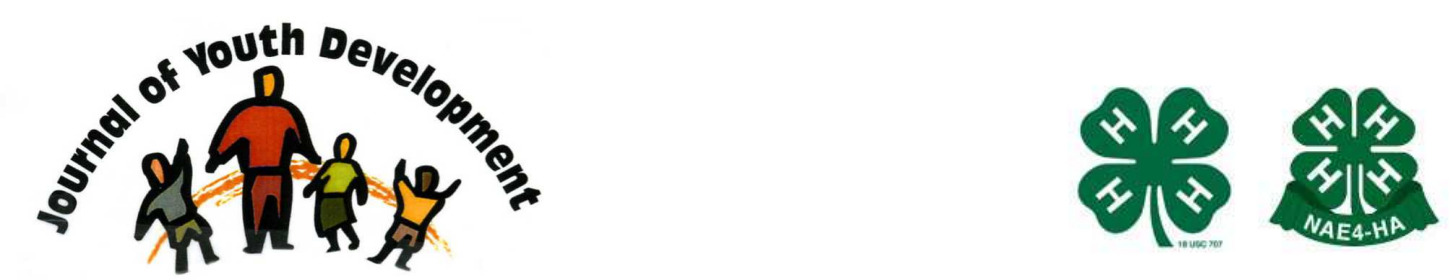

Bridging Research \& Practice

\title{
Factors Affecting Youth Voice in Decision-Making Processes within Youth Development Programs
}

\author{
Todd Tarifa \\ 4-H Youth Development \\ LSU Ag Center \\ Baton Rouge, LA \\ tatarifa@agcenter.Isu.edu \\ Krisanna Machtmes \\ School of Human Resource Ed \& Workforce Development \\ Louisiana State University \\ Baton Rouge, LA \\ machtme@lsu.edu \\ Janet E. Fox \\ 4-H Youth Development \\ LSU Ag Center \\ Baton Rouge, LA \\ jfox@agcenter.Isu.edu \\ Earl Johnson \\ LSU Ag Center \\ Baton Rouge, LA \\ ejohnson@agctr.Isu.edu
}




\title{
JOURNAL OF YOUTH DEVELOPMENT \\ bridging research and practice

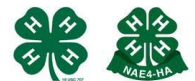

\section{Factors Affecting Youth Voice in Decision-Making Processes within Youth Development Programs}

\author{
Todd Tarifa, Krisanna Machtmes, Janet E. Fox and Earl Johnson \\ Louisiana State University
}

\begin{abstract}
Results of a study aimed at determining the factors affecting the level of inclusiveness of youth voice in the decision-making process of the 4-H youth development program are discussed in this paper. State and field level 4-H professionals identified potential factors which affect youth voice in the decision-making process. The information gathered was utilized to identify the degree to which youth voice was incorporated in the decision-making process, to better understand how to suit youth's needs, identify promising practices, and diagnose barriers towards fostering youth voice within the 4-H youth development program. This feature article presents the findings of the study, and discusses potential ramifications and remedies.
\end{abstract}

\section{Introduction}

Findings from a study aimed at determining the factors affecting the level of inclusiveness of youth voice in the decision-making process in the 4-H youth development program are presented in this article. State and field level 4-H professionals identified potential factors which affect youth voice in the decision-making process. The information gathered was utilized to identify the level of inclusiveness of youth voice in the decision-making process, to better understand how to suit youth's needs, identify promising practices, and diagnose barriers towards fostering youth voice within the $4-\mathrm{H}$ youth development program.

Four-H youth development professionals considered the following factors while examining perceptions of youth voice:

- the level in which both youth and adults share responsibility;

- lack of transportation accessible to youth;

- the ability of youth and adults to work cohesively;

- the opportunity for youth to develop a caring relationship with adults; 
- an adult's expectations of youth roles within the 4-H program;

- youths' expectations of adult roles within the 4-H program;

- the level in which the organization accepts youth involvement in the decision- making process; and

- youth having too many scheduling conflicts.

\section{Youth Voice}

The term youth voice has gained credibility as a concept which describes the many aspects in which youth might have the opportunities to a voice and active participation in the decisions shaping their lives (Fielding, 2001; Levin, 1999). Additionally, research implies that youth voice serves as a catalyst for change in schools, including helping to improve teaching, the curriculum, and adult youth relationships (Fielding, 2001; Mitra, 2003; Rudduck \& Flutter, 2000). Youth voice concerns considering the opinions and ideas of youth, with respect to what they have to say. It also involves taking risks and working together to accomplish the mission of the organization being served (Fletcher, 2002). When organizations practice youth voice, they give ample opportunities for youth to experience the adult roles for which they are preparing to assume. The general goal of engaging and empowering youth should be to teach them to define and express their concerns, and to design, discuss and put into action solutions to those concerns (Pittman \& Wright, 1991).

\section{Adults in Decision-Making Roles}

Although youth issues may be the main concern in the community or within the organization, adults are most often at the forefront of the decision-making process, with little discussion or input from youth. Based on several studies, adults are hesitant about youth and the role of youth in the decision-making process within society (Guzman, Lippman, Moore, \& O'Hare, 2003; Rennekamp, 1993; Zeldin et al., 2000). Through research, it has been well documented that stereotyping of youth by adults confines young peoples' potential within their community (Camino, 2000; Klindera \& Menderweld, 2001; Yohalem \& Pittman, 2001; Zeldin et al., 2000). Adults must realize that youth are up-to-date on current issues and events directly affecting themselves and their peers. Adults all too frequently perceive youth as consumers, and not resources, within the organization and community (Klindera \& Menderweld, 2001; Zeldin et al., 2000).

\section{Youth Voice on Boards and Committees}

The 4-H youth development program involves stakeholders in decision-making and program development processes, through the use of advisory committees that operate at the parish and state levels (Tassin, 2005). One part of the success of these committees is the inclusion of 4-H youth members. By allowing youth to have a voice, these committees have identified cutting edge programs that appeal to youth and have recognized barriers to youth participation, such as time, transportation, and lack of interest in existing programs (Tassin, 2005). Benson (1997) stated that allowing youth to serve on boards or committees in a meaningful role is one of the least likely experiences for youth in the present day. Many organizations fail to recognize that youth are talented, competent, and capable of bringing diverse ideas to bear. Several research studies have indicated that youth can decipher and resolve problems, if empowered through involvement in the decision-making process (Flanagan \& Faison, 2001; Kaba, 2000; Lerner, Ostrom, \& Freel, 1995; McLaughlin, Irby \& Langman, 1994; Villarruel, Perkins, Borden \& Keith, 2003; Zeldin, et al., 2000). Adults are a major influence in youths' lives; therefore, it is critical that youth development professionals serve as positive adult role models by mentoring, guiding, and connecting with youth. 


\section{Youth and Adult Partnerships}

Researchers have found that programs which provide a link between youth and adults help dismiss negative stereotypes youth and adults may hold about each other (Camino, 2000; Matters, 1990). It is important that a program (e.g. 4-H) provide rewarding experiences and opportunities for both youth and adults. Benson (1997) concluded that youth are frequently isolated from positive experiences with caring adults. In addition, Wunrow and Einspruch (2001) indicated that youth-adult partnerships are necessary in developing, implementing, and evaluating programs that impact youth. A less biased balance of power between adults and youth in the decision-making process is necessary as a means of valuing youth voice if youth are to benefit from these programs.

One of the most critical components to the success of youth voice is the youth-adult partnership. If the youth-adult partnership is negatively affected by poor attitudes, a lack of communication, or stereotyping, youth will struggle to become part of the decision-making process. The concepts of adultism and paternalism, where youth are not appreciated or respected by adults, play significant roles in limiting youth voice. Youth are viewed as less important, and adults are always superior when it comes to making decisions (Justinianno and Scherer, 2001; Pittman, Irby and Ferber, 2001). These barriers promote the concept that youth can not be trusted to develop correctly without being disciplined and guided into the adult world (Checkoway, 1996).

\section{Youth Voice Benefits}

Youth must be considered in the decision-making process, because they know the needs and wants of their peers, and understand how to effectively reach their peers (Kothari, 1996). It is important to include youth input in the decision-making process to foster individual and community growth and development. Kothari (1996) argued that the individual, the organization, and the community benefit from the process of youth participation. The individual benefits from the learning process and sense of connectedness of participation, while the organization and community benefit from the effectiveness of the projects (Kothari, 1996). O'Donoghue and Kirshner (2003) found that youth involved in community-based youth organizations honed important competencies through democratic participation, ranging from collaborative work and decision-making, to practical knowledge about local concerns and how to make an impact on them. The competencies youth gained from involvement in real-world, project-based programs were rarely available to them in traditional public schools. These opportunities for actual public work towards meaningful change meant that youth experienced the successes, challenges, and failures that only come from genuine encounters with complex public problems. Youth occasionally experienced frustration; however, this was viewed as part of a learning process which would enable them to continue their democratic work in other settings with new experiences and wisdom.

When youth participate in the decision-making process, they see themselves as persons who have some significance to add to the world (Pittman, 2000). The concept of youth voice has surfaced as an approach for improving the success of community and school reform efforts; thus far, few studies have examined this concept either in theory or empirically (Felix, 2003). However, youth advocates in the decades between 1960 and 2000 have contributed to a tremendous shift in youth policies and practices in America. Through this shift in paradigm, there has been a growing awareness of the combined efforts of youth, families, and community stakeholders working together to create, plan and implement projects (Pittman, 2000). Thus, youth are redefining both their roles in the decision-making process, and the efforts which affect or change the communities in which they live (Pittman \& Wright, 1991). Today's youth 
seek to have their views, beliefs, concerns, and input respected at levels of the decision-making process which not only affect them as individuals, but also affect the schools they attend, organizations they stand by, and communities in which they develop (Felix, 2003).

When youth develop strong, caring relationships with their communities, they are more likely to grow up safe and healthy, participate in educational, cultural and employment opportunities, and not become involved in violence and crime (Leifer \& McLarney, 1997). All-inclusive participation is a primary component of any civil society. Yet, opportunities and pathways for youth to engage the community remain limited due to the daily segregation of youth from adults and the negative public opinion of adolescents (Camino \& Zeldin, 2002). Therefore, youth voice and engagement are important means of overcoming the disrespect of young people, who can contribute to constructive and positive change for society (Stoneman, 2002).

\section{Youth Voice Challenges}

Youth voice models are valuable tools for actively engaging youth in the community. Yet, like most change efforts, achieving youth voice can pose a number of challenges. Common challenges arise from balancing the school/work schedules between youth and adults, and sustaining youth attention and loyalty. A number of challenges were identified by Justinianno and Scherer of the Points of Light Foundation (2001).

Logistical and organization: Adults whom support the concept of youth-adult partnerships and youth voice must also be prepared to identify and adjust the organization's environment (where institutional barriers can be particularly significant for youth). Such institutional barriers as hours for meetings and work, transportation, food, equipment and support, procedures and policies, and training make legitimate youth-adult partnerships and youth voice difficult.

Sharing power: Some adults have trouble yielding power to youth during the planning and decision-making process. Simultaneously, some youth may be uncomfortable with assuming the accountability and responsibility that comes with having power.

Stereotypes: Many adults reach out to youth that they think will act and perform like adults. As a result, it may be easier to engage youth whom have already been identified as leaders. Youth also have stereotypes of adults, which may lead to lack of confidence, expectations, or skepticism about adults' enthusiasm to support and partner with them.

Viewing youth as recipients: Many adults and youth have difficulty seeing youth as leaders or resources in the social order. Some do not consider or believe that youth could offer worthwhile or valuable contributions to the community (Justinianno \& Scherer, 2001).

Newsome and Scalera (2001) found that youth whom were interviewed stated they felt disconnected, alienated, unsupported, unacknowledged, and disrespected by adults within the organization. Positive youth-adult partnerships are critical to engaging youth in the decisionmaking process. Adults must share power with youth to keep them involved (Justinianno \& Scherer, 2001; Young \& Sazama, 1999; Zeldin et al., 2000). One of the recurring barriers to youth voice identified by both youth and adults in the literature is the lack of orientation and training. Similarly, it has been shown that youth are negatively affected when adults do not clearly communicate their expectations (Princeton Survey Research Associates, 1998). Scheduling conflicts with youth participants in decision-making processes are another barrier identified in research. The research has specified that youth generally lack for time, and the organization's resistance to flexible scheduling of meetings at times typically convenient for 
youth to attend generate barriers to youth participation (Hoover \& Weisenbach, 1999; Kurkoski et al., 1997; Newsome \& Scalera, 2001; Parker, 1998; Parker, 1999; Princeton Survey Research Associates, 1998). In addition, there are technical obstacles that act as barriers to youth that want to be involved in decision-making process, such as transportation (Parker, 1999) and youth being denied access to resources they need to be successful (Checkoway, 1996).

Some barriers documented in a study conducted by Hart (1992) included the youth's level of self-esteem, their basic capability in taking the perspective of another person, their level of academic development, and child-rearing practices that instill youth with different attitudes. In addition, youth whom are disadvantaged, disabled, or lacking attention may also have been denied the opportunity to contribute in the decision-making process (Australian Youth Foundation, 1996). Other barriers to participation could include: the amount of time available by young people; a lack of skills, training and/or experience; a lack of resources; an adult "mind set" against youth input or fear of losing power; and an organizational, community or cultural opposition (International Youth Foundation, 1996).

\section{Methodology}

A descriptive-correlational study was conducted to describe the 4-H organization's views on youth voice in the decision-making process. Dillman's (2000) survey design and methodology was followed in the study.

\section{Population and Sample}

This was a national study, which was designed to gather information from three different populations that are significant and essential groups of the 4-H youth development program. The accessible population consisted of the following three groups:

(1) the State 4-H Program Leaders in all 50 states,

(2) the State 4-H Youth Development Specialists in all 50 states, and

(3) five 4-H Youth Agents/Educators in Cooperative Extension county/parish offices in each state whom have assigned 4-H duties as identified by their State 4-H Program Leader.

The first population is the target population of 4-H Program Leaders in all 50 states. These individuals were identified through the USDA Cooperative State Research, Education, and Extension Service website directory. The second population was the accessible population of 4-H Youth Development Specialists in each state. These individuals were also identified through the USDA Cooperative State Research, Education, and Extension Service website directory. All 50 State 4-H Offices were contacted to verify 4-H Youth Development Specialists. The third population was the accessible population of 4-H Youth Agents/Educators, whom were identified by the State 4-H Program Leader in each state. Each 4-H State Program Leader was asked to identify five 4-H Youth Agents/Educators, based on the diversity and demographics of their state, to complete the survey. Prior to the survey, a letter was sent via e-mail to each state's 4-H Program Leader, 4-H Youth Development Specialists, and 4-H Youth Agents / Educators to notify them of the study.

\section{Survey Instrument and Procedure}

The instruments were developed based on empirical literature. Specific questions have been developed in order to determine respondents' perceptions on barriers affecting youth voice in the decision-making process within the 4-H program, and obtain demographics for the populations sampled. Participants were asked to indicate the issues that affect youth voice in 
the decision-making process by rating their perceptions on a five-point anchored Likert-type scale: "Never," "Seldom," "Sometimes," "Often," and "Always." The instrument was also utilized to collect the following demographic data: gender, highest level of education, ethnicity, participation in other youth organizations, years served as a 4-H youth development professional, and the number and hours of trainings attended on youth voice. The instruments were reviewed by an expert panel prior to data collection to determine content validity. The panel was made up of a volunteer specialist with 20 years of experience, two researchers/ practitioners with 20 years of experience each, and a panel of 30 youth whose ages ranged from 14 to 18 years old.

\section{Data Collection}

Data was collected by the researcher after administering the instrument via Zoomerang(C) (electronic survey software) to each state's 4-H Program Leader, 4-H Youth Development Specialists, and 4-H Youth Agents/Educators (selected by the State 4-H Program Leaders to complete the survey) surveyed in this study. All participants were sent electronically a brief cover letter that requested their participation, provided instructions for completing the survey, and contained a URL link to the survey. Dillman's survey techniques (Dillman, 2000) were used to encourage the participation in the study of sample subjects, and to follow up with nonrespondents.

There were 50 State 4-H Program Leaders, 406 4-H Youth Development Specialists, and 250 4-H Agents/Educators invited to participate in the study. A total of 706 participants were asked to complete the survey during the time period extending from May 17, 2006 through July 27, 2006. Participants were assured confidentiality in completing the survey.

\section{Results}

The objective was to determine the perceptions of State 4-H Program Leaders, State 4-H Youth Development Specialists, and 4-H Youth Agents/Educators throughout the United States regarding their views on the factors affecting youth voice in the decision-making process. The responses from which respondents could choose were as follows: "1 = Never," "2 = Seldom," "3 = Sometimes," "4 = Often," "5 = Always."

The following interpretive scale was developed for the perception mean scores, as it pertains to factors that affect the level of youth voice in the 4-H program:

- mean scores ranging from 1.00 to 1.50, were interpreted as "Never" affecting youth voice;

- mean scores ranging from 1.51 to 2.50 , were interpreted as "Seldom" affecting youth voice;

- mean scores ranging from 2.51 to 3.50, were interpreted as "Sometimes" affecting youth voice;

- mean scores ranging from 3.51 to 4.50, were interpreted as "Often" affecting youth voice; and

- mean scores ranging from 4.51 to 5.00, were interpreted as "Always" affecting youth voice.

When State 4-H Program Leaders were asked to select the most appropriate response to the statements included on the survey instrument, thirteen items on the scale were interpreted as "Often" being factors which affect the level of youth voice in the decision-making process in the 4-H program. Twenty-one items were interpreted as "Sometimes" being a factor that affects 
the level of youth voice in the decision-making process in the 4-H program, and one was interpreted as "Seldom" being a factor which affects the level of youth voice in the decisionmaking process in the 4-H program. Cronbach's alpha measure of reliability (internal consistency) was calculated for the section of the instrument that determined the factors affecting youth voice as perceived by the State 4-H Program Leaders. Cronbach's alpha was calculated to be .939 , which according to Hair et al. (1998) indicates acceptable reliability.

Data regarding the perceptions of State 4-H Program Leaders on the factors affecting youth voice in the decision-making process within the $4-\mathrm{H}$ program are presented in Table 1 . The factors perceived as most and least important to developing and supporting youth voice in the decision-making process within the $4-\mathrm{H}$ program are presented.

\section{Table 1}

\begin{tabular}{|l|c|c|c|c|}
\hline State 4-H Program Leader & $\underline{\mathrm{n}}$ & Mean & $\underline{\mathrm{SD}}$ & Interpretation \\
\hline $\begin{array}{l}\text { The level in which both adults and youth share } \\
\text { responsibilities within the program affects youth voice in } \\
\text { the 4-H program. }\end{array}$ & 32 & 4.09 & .59 & Often \\
\hline $\begin{array}{l}\text { The level in which the organization accepts youth } \\
\text { involvement in the decision making process affects } \\
\text { youth voice in the 4-H program. }\end{array}$ & 32 & 3.84 & .81 & Often \\
\hline $\begin{array}{l}\text { An adult's expectations of youth roles within the 4-H } \\
\text { program affects youth voice. }\end{array}$ & 32 & 3.81 & .64 & Often \\
\hline $\begin{array}{l}\text { The ability of youth and adults to work as a team affects } \\
\text { youth voice in the 4-H program. }\end{array}$ & 32 & 3.78 & .79 & Often \\
\hline $\begin{array}{l}\text { Both youth and adults awareness of the 4-H program's } \\
\text { policies affects youth voice in the 4-H program. }\end{array}$ & 32 & 3.78 & .66 & Often \\
\hline $\begin{array}{l}\text { An adult's past negative experiences when being } \\
\text { involved in 4-H affects youth voice in the 4-H program. }\end{array}$ & 32 & 3.06 & 1.01 & Sometimes \\
\hline $\begin{array}{l}\text { The level of recognition for youth in the 4-H program } \\
\text { affects youth voice in the 4-H program. }\end{array}$ & 32 & 3.03 & .97 & Sometimes \\
\hline $\begin{array}{l}\text { The decision making skills of youth affects youth voice } \\
\text { within the 4-H program. }\end{array}$ & 32 & 3.00 & .88 & Sometimes \\
\hline $\begin{array}{l}\text { The level of recognition for adults in the 4-H program } \\
\text { affects youth voice in the 4-H program. }\end{array}$ & 32 & 2.81 & 1.07 & Sometimes \\
\hline $\begin{array}{l}\text { Whether food is provided at activities/programs affects } \\
\text { youth voice in the 4-H program. }\end{array}$ & 32 & 2.22 & .83 & Seldom \\
\hline
\end{tabular}

Note. Response based on Likert-type scale with values: $1=$ Never, 2 = Seldom, $3=$ Sometimes, 4 = Often, 5 =Always

Interpretive scale: 1.00 to $1.50=$ Never; 1.51 to $2.50=$ Seldom; 2.51 to $3.50=$ Sometimes;

3.51 to $4.50=$ Often; and 4.51 to $5.00=$ Always. 
When 4-H Youth Development Specialists were asked to select the most appropriate response to the statements included on the survey instrument, fourteen items on the scale were interpreted as "Often" being factors that affect the level of youth voice in the decision-making process in the 4-H program. Twenty-two items were interpreted as "Sometimes" being factors affecting the level of youth voice in the decision-making process in the 4-H program.

Cronbach's alpha measure of reliability (internal consistency) was calculated for the section of the instrument which determined the factors affecting youth voice as perceived by 4-H Youth Development Specialists. Cronbach's alpha was calculated to be .924, which indicates acceptable reliability (Hair et. al, 1998).

Data regarding the perceptions of 4-H Youth Development Specialists on the factors which affect youth voice in the decision-making process within the 4-H program are presented in Table 2. The factors perceived as most and least important to developing and supporting youth voice in the decision-making process within the 4-H program are presented.

Table 2

\begin{tabular}{|l|c|c|c|c|}
\hline 4-H Youth Development Specialist & $\underline{\mathrm{n}}$ & Mean & $\underline{\text { SD }}$ & Interpretation \\
\hline $\begin{array}{l}\text { The level in which both adults and youth share responsibilities } \\
\text { within the program affects youth voice in the 4-H program. }\end{array}$ & 187 & 4.26 & .65 & Often \\
\hline $\begin{array}{l}\text { The level in which the organization accepts youth involvement } \\
\text { in the decision making process affects youth voice in the 4-H } \\
\text { program. }\end{array}$ & 187 & 4.01 & .82 & Often \\
\hline $\begin{array}{l}\text { An adult's expectations of youth roles within the 4-H program } \\
\text { affects youth voice. }\end{array}$ & 187 & 3.94 & .71 & Often \\
\hline $\begin{array}{l}\text { Youth having too many scheduling conflicts affects youth } \\
\text { voice in the 4-H program. }\end{array}$ & 187 & 3.90 & .64 & Often \\
\hline $\begin{array}{l}\text { The ability of youth and adults to work as a team affects youth } \\
\text { voice in the 4-H program. }\end{array}$ & 187 & 3.86 & .80 & Often \\
\hline $\begin{array}{l}\text { An adult's fear of sharing their ideas with youth affects youth } \\
\text { voice in the 4-H program. }\end{array}$ & 187 & 3.22 & .90 & Sometimes \\
\hline $\begin{array}{l}\text { The level of recognition for youth in the 4-H program affects } \\
\text { youth voice in the 4-H program. }\end{array}$ & 187 & 3.18 & .89 & Sometimes \\
\hline $\begin{array}{l}\text { Adult's lack of self-esteem affects the level of youth voice in } \\
\text { the 4-H program. }\end{array}$ & 187 & 3.09 & .90 & Sometimes \\
\hline $\begin{array}{l}\text { A lack of communication skills by youth affects youth voice } \\
\text { within the 4-H program. }\end{array}$ & 187 & 3.04 & .84 & Sometimes \\
\hline $\begin{array}{l}\text { Whether food is provided at activities/programs affects youth } \\
\text { voice in the 4-H program. }\end{array}$ & 187 & 2.78 & .91 & Sometimes \\
\hline $\begin{array}{l}\text { The level of recognition for adults in the 4-H program affects } \\
\text { youth voice in the 4-H program. }\end{array}$ & 187 & 2.77 & .79 & Sometimes \\
\hline
\end{tabular}

Note. Response based on Likert-type scale with values: $1=$ Never, 2 = Seldom, 3 = Sometimes, 4 = Often, 5 = Always

Interpretive scale: 1.00 to $1.50=$ Never; 1.51 to $2.50=$ Seldom; 2.51 to $3.50=$ Sometimes; 3.51 to $4.50=$ Often; and 4.51 to $5.00=$ Always.

When 4-H Agents/Educators were asked to select the most appropriate response to the statements included on the survey instrument, fifteen items on the scale were interpreted as "Often" being factors which affected the level of youth voice in the decision-making process 
within the 4-H program. Twenty-one items were interpreted as "Sometimes" being factors affecting the level of youth voice in the decision-making process within the 4-H program. Cronbach's alpha measure of reliability (internal consistency) was calculated for the section of the instrument which determined the factors affecting youth voice as perceived by the 4-H Agents/Educators. Cronbach's alpha was calculated to be .954, which indicates acceptable reliability (Hair et. al, 1998).

Data regarding the perceptions of 4-H Agents/Educators on the factors which affect youth voice in the decision-making process within the $4-\mathrm{H}$ program are presented in Table 3 . The factors perceived as most and least important to developing and supporting youth voice in the decisionmaking process within the $4-\mathrm{H}$ program are presented.

\section{Table 3}

\begin{tabular}{|l|c|c|c|c|}
\hline 4-H Agents/Educators & $\underline{\mathrm{n}}$ & Mean & $\underline{\text { SD }}$ & Interpretation \\
\hline $\begin{array}{l}\text { The level in which both adults and youth share } \\
\text { responsibilities within the program affects youth } \\
\text { voice in the 4-H program. }\end{array}$ & 130 & 4.14 & .78 & Often \\
\hline $\begin{array}{l}\text { Youth having too many scheduling conflicts } \\
\text { affects youth voice in the 4-H program. }\end{array}$ & 130 & 3.98 & .86 & Often \\
\hline $\begin{array}{l}\text { The ability of youth and adults to work as a team } \\
\text { affects youth voice in the 4-H program. }\end{array}$ & 130 & 3.89 & .81 & Often \\
\hline $\begin{array}{l}\text { The level in which the organization accepts youth } \\
\text { involvement in the decision making process } \\
\text { affects youth voice in the 4-H program. }\end{array}$ & 130 & 3.88 & .95 & Often \\
\hline $\begin{array}{l}\text { Youth understanding their role affects youth } \\
\text { voice in the 4-H program. }\end{array}$ & 130 & 3.82 & .83 & Often \\
\hline $\begin{array}{l}\text { Youth not having enough program options to } \\
\text { participate in 4-H affects youth voice in the 4-H } \\
\text { program. }\end{array}$ & 130 & 3.20 & 1.02 & Sometimes \\
\hline $\begin{array}{l}\text { Adult's fear of failing affects youth voice in the } \\
\text { 4-H program. }\end{array}$ & 130 & 3.16 & .97 & Sometimes \\
\hline $\begin{array}{l}\text { An adult's fear of sharing their ideas with youth } \\
\text { affects youth voice in the 4-H program. }\end{array}$ & 130 & 3.15 & .99 & Sometimes \\
\hline $\begin{array}{l}\text { Whether food is provided at activities/programs } \\
\text { affects youth voice in the 4-H program. }\end{array}$ & 130 & 2.99 & 1.08 & Sometimes \\
\hline $\begin{array}{l}\text { The level of recognition for adults in the 4-H } \\
\text { program affects youth voice in the 4-H program. }\end{array}$ & 130 & 2.90 & .87 & Sometimes \\
\hline
\end{tabular}

Note. Response based on Likert-type scale with values: $1=$ Never, $2=$ Seldom, $3=$ Sometimes, 4 = Often, 5 = Always

Interpretive scale: 1.00 to $1.50=$ Never; 1.51 to $2.50=$ Seldom; 2.51 to $3.50=$ Sometimes;

3.51 to $4.50=$ Often; and 4.51 to $5.00=$ Always. 


\section{Conclusion}

When examining 4-H youth development professionals' perceptions on the factors affecting youth voice in the decision-making process within the 4-H Youth Program, respondents considered several causes, which affect youth voice in the decision-making process. These issues included the level at which both youth and adults share responsibility, lack of available transportation, and the ability of youth and adults to work as a team. Additional factors included the opportunity for youth to develop a caring relationship with adults, an adult's expectations of youth roles within the 4-H program, and youth's expectations of adult roles within the 4-H program. Further, both youths' and adults' awareness of the 4-H program's policies, the level in which the organization accepts youth involvement in the decision-making process, and youth having too many scheduling conflicts were also considered as barriers impacting youth voice by $4-\mathrm{H}$ youth development professionals.

Important patterns regarding the perceptions of $4-\mathrm{H}$ youth development professionals, agents/ educators, and state leaders regarding factors which affect youth voice in the decision-making process within the 4-H Youth Program emerge upon reviewing the results of this study. Each of the 4-H three groups included in this study (youth development professionals, agents/ educators, and state leaders) unanimously perceive that the level of responsibility shared between adults and youth represents the single most important factor that affects youth voice in the decision-making process within the 4- $\mathrm{H}$ Youth Program. Similarly, the level at which the organization accepts youth involvement in the decision-making process was also unanimously indicated as an important factor affecting youth voice within $4-\mathrm{H}$ programs. Further, the ability of youth and adults to work as a team within the organization was also unanimously prescribed as one of the most important factors affecting youth voice in the decision-making process within the 4-H Youth Program.

These factors, unanimously perceived as having most important affects upon youth voice in the decision-making process within the 4-H Youth Program (shared responsibility, acceptance, and teamwork), are well supported within the literature. The need for shared responsibility and teamwork between youth and adults within organizations and programs is highlighted by Benson (1997) and Wunrow and Einspruch (2001). Acceptance of youth in the decision-making process within organizations is strongly supported and advocated by Kothari (1996), for the benefit of both youth involved and the organization. These findings are further supported and expanded upon by O'Donoghue and Kirshner (2003). That the factors of shared responsibility and teamwork between youth and adults for purposes of decision-making, and the acceptance of the role of youth within the decision-making process, are perceived by all surveyed groups as affecting youth voice is a positive indication that 4-H programs successfully foster youth involvement. This agrees with the findings of Tassin (2005).

Other results, however, are not congruent with the literature. Results indicate that only 4-H youth development specialists and agents/ instructors perceive scheduling conflicts of youth as greatly affecting youth voice in decision-making process within 4-H programs, while state 4-H leaders perceive other factors as having greater affect. Four- $\mathrm{H}$ youth development specialists and agents/ instructors, and not state leaders, also perceive adults' fear of sharing their ideas with youth as minimally affecting youth voice in decision-making processes within $4-\mathrm{H}$ programs. State 4-H leaders and youth development professionals perceive recognition of youths' contributions as only "Somewhat" affecting youth voice in decision-making processes within 4-H programs. The provision of food at activities/ programs was unanimously perceived 
by all three groups as one of the two least important factors affecting youth voice in the decision-making process within 4-H programs.

These results are incongruent with the literature. The importance of logistic details - such as scheduling, recognizing contributions, and the provision of modest comforts such as food - for fostering youth voice in the decision-making processes of programs has been well established (Justinianno and Scherer, 2001; Newsome and Scalera, 2001; and Princeton Survey Research Associates, 1998). Adults' fears of sharing ideas with youth in the decision-making processes of programs can represent negative attitudes of youth held by adults, and create barriers that impede progress (Checkoway, 1996; Pittman, Irby, and Ferber, 2001; and Justinianno and Scherer, 2001). These results may indicate difficulties that still exist within 4-H programs, despite efforts to include youth in the decision-making processes of the organization.

\section{Recommendation}

Such issues as transportation will always be a dilemma, and will often retard progress especially when dealing with youth. However, remaining factors which serve as barriers to youth voice can be remedied with proper training on youth voice, preparation for youth voice (orientation, position descriptions, etc.), and involvement. If such steps are taken, youth and adults can become partners, and develop meaningful relationships which provide the respect and trust needed for youth voice to thrive. Research has shown that one of the most critical components to the success of youth voice is the youth-adult partnership. If the youth-adult partnership is negatively affected by poor attitudes, a lack of communication, or stereotyping, youth struggle to become part of the decision-making process. The concept of adult power and control (adultism) plays a significant role in the failure of youth voice.

As youth development professionals, we can not deem youth less important than adults to the decision making process. Nor should it be assumed that adults are always superior to youth when making decisions. Adults whom control the program and do not allow youth voice in the decision-making process are a critical barrier; they insinuate that youth can not be trusted to develop correctly without being disciplined and guided into the adult world (Checkoway, 1996). Additionally, communicating high standards and clear expectations to all individuals involved, and making sure that meeting times, locations, transportation, and other logistic details are flexible and available for youth have been identified as effective practices which foster an environment conducive for youth voice (Carstarphen, 2001; Checkoway et al., 2003; Justinianno \& Scherer, 2001; Kurkoski et al., 1997; Mason \& Goll, 2000; Parker, 1998; Young \& Sazama, 1999; Zeldin et al., 2000).

\section{References}

Australian Youth Foundation (1996). Youth Partnership \& Participation. Retrieved March 4, 2005 from www.af.org.au

Benson, P. (1997). All kids are our kids. San Francisco, CA: Jossey-Bass, Inc.

Camino, L. (2000). Putting youth-adult partnerships to work for community change: Lessons from volunteers across the country. CYD Journal, 1(4), 27-31.

Camino, L., \& Zeldin, S. (2002). From periphery to center: pathways for youth civic engagement in the day-to-day life of communities. Applied Environmental Sciences, 6(4), 213-220. 
Carstarphen, D. (2001). The Role of Young People in the Leadership Organization. Washington, DC: Academy for Educational Development.

Checkoway, B. (1996). Adults as Allies. University of Michigan, Ann Arbor, MI: W.K. Kellogg Foundation. Retrieved on March 26, 2005 from http://www.wkf.org/Pubs/YouthED/pub564.pdf

Checkoway, B., Figueroa, K., \& Richards-Schuster, K. (2003). Democracy multiplied in an urban neighborhood: Youth force in the South Bronx. Children, Youth and Environment, 13, 15462250.

Dillman, D. (2000). Mail and Internet Surveys, 2nd Ed. New Yourt, NY: John Wiley \& Sons.

Felix, A. (2003). Making Youth Voice A Community Principle. Retrieved March 6, 2005 from http://www.ysa.org/yvi/resources/MakingYouthVoiceACommunityPrinciple.pdf.

Fielding, M. (2001). Special issue: Student voice. Forum, 43(2), 49-59.

Flanagan, C., \& Faison, N. (2001). Youth civic development: Implications of research for social policy and programs. Social Policy Report, 9(1). Ann Arbor, MI: Society for Research in Child Development.

Fletcher, A. (2002). Broadening the Bounds of Involvement: Transforming Schools With Student Voice. Retrieved March 6, 2005 from www.studentinvolvement.net.

Guzman, L., Lippman, L., Moore, K., \& O'Hare, W. (2003). Public perception of children's wellbeing. Washington, DC: Childtrends and Annie Casey Foundation.

Hair, J., Anderson, R., Tatham, R., \& Black, W. (1998). Multivariate data analysis (5 ${ }^{\text {th }}$ ed.). Upper Saddle River, NJ: Prentice-Hall.

Hart, R. (1992). Children's Participation: Tokenism to Citizenship. UNICEF.

Hoover, A., \& Weisenbach, A. (1999). Youth leading now! Securing a place at the table. New Designs for Youth Development. 15(3), 29-35. retrieved on March 21, 2005 from http://www.cydjournal.org/NewDesigns/ND 99Sum/Hoover.html

International Youth Foundation (1996). Youth Participation: Challenges and Opportunities, 1996 Meeting Report.

Justinianno, J., \& Scherer, C. (2001). Youth Voice: A Guide for Engaging Youth in Leadership and Decision-Making in Service-Learning Programs. Washington, DC: Points of Light Foundation.

Kaba, M. (2000). They listen to me...but they don't act on it: Contradictory consciousness in decision-making. High School Journal, 84(2), 21-35.

Klindera, K., \& Menderweld, J. (2001). Youth involvement in prevention programming. Issues at a Glance. Retrieved on October 29, 2006 from http://www.advocatesforyouth.org/publications/iag/involvement.htm

Kothari, R. (1996, December). Youth participation in youth development. Paper presented at the Annual Meeting of the Comparative and International Education Society in Mexico City, Mexico. 
Kurkoski, J., Markendorf, K., \& Straw, N. (1997). Youth Voice Begins with You! Seattle, WA: Washington Youth Voice Project.

Leifer, L., \& McLarney, M. (1997). Stronger Voices, Better Choices: Promise Project's Guide to Forming Youth/Adult Partnerships. Promise Project, YMCA of Greater Kansas City, Kansas City, MO, 4-5.

Lerner, R., Ostrom, C., \& Freel, M. (1995). Promoting positive youth and community development through outreach scholarship: Comments on Zeldin and Pererson. Journal of Adolescent Research, 10(4), 486-502.

Levin, B. (1999). Putting students at the centre in education reform. Winnipeg, Canada: Lofquist, W. (1993). The Technology of Prevention Workbook: A Leadership Development Program. Tucson, Arizona: Associates for Youth Development, Inc.

Mason, H., \& Goll, R. (2000). Youth-adult review of research findings: Hampton Coalition for Youth (Appendix A). In Zeldin, S., McDaniel, A., Toptizes, D., \& Calvert, M. Youth indecisionmaking. Washington, DC: National 4-H Council. Retrieved march 5, 2005 from www.atthetable.com.

Matters, L. (1990). Intergenerational relations: Older adults and youth. County extension program guide. University of Missouri, Columbia. Center on Rural Elderly.

McLaughlin, M., Irby, M., \& Langman, J. (1994). Urban sanctuaries: Neighborhood organizations in the lives and futures of inner-city youth. San Francisco: Jossey-Bass.

Mitra, D. (2003). Student voice in school reform: Reframing student-teacher relationships.

McGill Journal of Education, 38(2), 289-304. retrieved on February 27, 2006 from

www.education.mcgill.ca/edmje

Newsome, J., \& Scarela, J. (2001). Youth and Boards: What's the Status? San Francisco: Youth Leadership Institute. Retrieved on May 4, 2005 from

http://www.theinnovationcenter.org/store/99

O'Donoghue, J., \& Kirshner, B. (2003). Urban Youth's Civic Development in Community Based Youth Organizations. Presented at the International conference on Civic Education, New Orleans, LA.

Parker, L. (1998). Supporting Organizations to Provide Youth Opportunities for Youth: An Interest and Needs Survey. Portland, OR: Portland Area Council of Campfire.

Parker, L. (1999). If All Youth Served: Empowering Youth to Build Community Through Service. Scottsdale, AZ: Corporation for National Service. Retrieved March 5, 2005 from http://www.cns.gov

Pittman, K. (2000). Balancing the equation: Communities supporting youth, youth supporting communities. Community Youth Development Journal, 1, 33-36.

Pitman, K., Irby, R., \& Ferber, T. (2001). Youth Action: Supporting a New Generation of Citizens. Community, Spring/Summer. Retrieved on March 6, 2005 from http://www.forumforyouthinvestment.org 
Pittman, K., \& Wright, M. (1991). Bridging the Gap: A Rationale for Enhancing the Role of community Organizations in Promoting Youth Development. Washington, DC: Center for Youth development and Policy Research.

Princeton Survey Research Associates. (1998). Youth People's Community Involvement Survey: Report on the Findings. New York: Do Something.

Rennekamp, R. (1993). Double Standard for Youth Involvement. Journal of Extension, 31(3). Retrieved on July 21, 2006 from http://www.joe.org/joe/1993fall/f2.html

Rudduck, J., \& Flutter, J. (2000). Pupil participation and pupil perspective: Carving out a new order of experience. Cambridge Journal of Education, 30, 75-89.

Stoneman, D. (2002). The role of youth programming in the development of civic engagement. Applied Developmental Science, 6(4), 221-226.

Tassin, M. (2005). Effectiveness of the 4-H Advisory Committee Process as Perceived by 4-H Professionals and Advisory Committee Members. Unpublished dissertation, Louisiana State University, Baton Rouge, Louisiana. Retrieved on February 12, 2005 from www.etd.Isu.edu/docs/submitted/etd 07082005154655/unrestricted/Tassin.thesis.pdf

Villarruel, F., Perkins, D., Borden, L., \& Keith, J. (2003). Community youth development: Practice, policy, and research. Thousand Oaks, CA: Sage.

Wunrow, J., \& Einspruch, E. (2001). Promoting youth/adult partnerships: The seven circles coalition in Sitka, Alaska. Journal of Primary Prevention, 22(2), 169-185.

Yohalem, N., \& Pittman, K. (2001). Powerful pathways: Framing options and opportunities for vulnerable youth. Discussion paper of the Youth Transition Funders Group. Washington, DC: The Forum for Youth Investment.

Young, K., \& Sazama, J. (1999). 14 Points: Successfully Engaging Youth I Decision making. Somerville, MA: Youth on Board.

Zeldin, S., McDanile, A., Toptzes, D., \& Calvert, M. (2000). Youth in Decision-Making: A Study on the Impacts of Youth on Adults and Organizations. Chevy Chase, MD: Innovation Center for Community and Youth Development.

(C) Copyright of Journal of Youth Development $~$ Bridging Research and Practice. Content may not be copied or emailed to multiple sites or posted to a listserv without copyright holder's express written permission. However, users may print, download or email articles for individual use. 